\title{
Concomitant infections, parasites and immune responses
}

\author{
F. E. G. COX* \\ Department of Infectious and Tropical Diseases, London School of Hygiene and Tropical Medicine, Keppel Street, \\ London WC1E $7 H T$, UK \\ S U M M A R Y
}

Concomitant infections are common in nature and often involve parasites. A number of examples of the interactions between protozoa and viruses, protozoa and bacteria, protozoa and other protozoa, protozoa and helminths, helminths and viruses, helminths and bacteria, and helminths and other helminths are described. In mixed infections the burden of one or both the infectious agents may be increased, one or both may be suppressed or one may be increased and the other suppressed. It is now possible to explain many of these interactions in terms of the effects parasites have on the immune system, particularly parasite-induced immunodepression, and the effects of cytokines controlling polarization to the Th or $\mathrm{Th}_{2}$ arms of the immune response. In addition, parasites may be affected, directly or indirectly, by cytokines and other immune effector molecules and parasites may themselves produce factors that affect the cells of the immune system. Parasites are, therefore, affected when they themselves, or other organisms, interact with the immune response and, in particular, the cytokine network. The importance of such interactions is discussed in relation to clinical disease and the development and use of vaccines.

Key words: Concomitant infections, cytokines, protozoa, helminths, bacteria, viruses.

\section{INTRODUCTION}

The term concomitant infections, alternatively called mixed infections, traditionally refers to a situation in which two or more infectious agents coexist in the same host. In the light of modern concepts of biology this definition is insufficiently precise and the definition that will be used here is one in which the two (or more) concomitant infectious agents are specifically designated as being genetically different. This definition permits the inclusion of agents belonging to different species, the commonly accepted view of concomitant infections, and members of the same species that are genetically different, for example those belonging to a different strain or population. In nature, concomitant infections are the rule and this has been recognized since the earliest recorded times; for example, multiple infections of helminth eggs have been detected in human coprolites and other human remains from prehistoric sites (see Brothwell \& Sandison, 1967; Cockburn, Cockburn \& Reyman, 1998). What is less well known is that there are numerous interactions, both gross and subtle, between different kinds of organisms. This fact has been long recognized by experimental scientists, including parasitologists, who go to great lengths to use animals that are germ free, specific pathogen free $(\mathrm{SPF})$ or harbour a known fauna or flora (gnotobiotic). Despite the widespread acceptance that different organisms commonly occurring together in the same hosts can, and do, influence one another directly or indirectly,

* Tel: +440207927 2333, Fax: +4402075809075.

E-mail: f.cox@1shtm.ac.uk field workers and other parasitologists seldom consider more than the single organism that directly concerns them. The standard parasitological text books are silent on this subject and there is virtually nothing about concomitant infections in the more specialized texts on epidemiology (Anderson \& May, 1991 ; Grenfell \& Dobson, 1995; Isham \& Medley, 1996), parasitism and host behaviour (Barnard \& Behnke, 1990; Beckage, 1997), helminth infections and nutrition (Stephenson, 1987), evolution (Brooks \& McLennan, 1993), immunology (Wakelin, 1996) or even host-parasite relationships ('Toft, Aeschlimann \& Bolis, 1991). There is some tangential reference to hormonal changes induced by parasites and possible effects on other parasites by Hillgarth \& Wingfield (1995) but this is not pursued in any depth. There is, therefore, a major gulf between the well defined world of text book parasitology, with everything laid out in neat selfcontained sections, and the nicely controlled conditions that exist in a laboratory, where there is usually a one to one parasite-host relationship, and the real world in the field where there may be many infections interacting with one another. There are many examples of concomitant infections in humans and animals (see for example Christensen et al. 1987; Ashford, 1991; Petney \& Andrews, 1998; Viera et al. 1998). The infectious agents concerned may be those of the same species, related species or distantly related species. Among the best known examples of the interactions between parasites of the same species are the schistosomes where the presence of an ongoing infection of adult worms inhibits the establishment of a subsequent infection by larval forms, a phenomenon known as concomitant im- 
munity (Smithers, Terry \& Hockley, 1969). This phenomenon is also seen in other helminth infections, for example, cestodes (see Heath, 1995). In malaria, an ongoing infection is thought by many workers not only to induce, but also to be necessary for immunity to a superimposed infection of parasites with the same or different genotype, a phenomenon called premunition (Sergent, 1937; Smith et al. 1999). Well known examples of interactions between more distantly related organisms are those that exist between the Epstein Barr virus and malaria parasites (Burkitt, 1969) and between the Human Immunodeficiency Virus (HIV) and several parasites of which the best known examples are Cryptosporidium and Leishmania spp. (see Ambroise-Thomas, this supplement).

One of the reasons why so little attention has been paid to concomitant infections is that the interactions involved are complex and difficult to understand. Briefly, such interactions can either be ecological, in which case the rules of ecology, particularly competition for space or resources, apply or immunological where the rules immunology apply. Anderson (1994) has stated, in another context, that 'the interaction between the variables that determine the typical course of infection in an individual patient and those that determine the typical course of infection in communities of people is often complex and very non-linear in form'. Everything that is said and implied here is made even more complex in the case of mixed infections. A number of ecologists, particularly those working with helminths, have begun to appreciate and take cognizance of mixed infections and their implications and a considerable amount of progress has been made in this area (Dobson, 1985, 1990; Poulin, 1998) and some of these aspects will be discussed further in this supplement by Dobson, Poulin, and Kennedy. However, the more subtle interactions that occur in hosts co-infected with more than one infectious agent, particularly those involving immunological responses, have been less well investigated and this is the area that will be considered in this article.

\section{THE NATURE OF THE INFECTED HOST}

It is a truism that a host harbouring any infectious agent is not the same as one that is not infected. Furthermore, hosts harbouring large numbers of parasites are not the same as those harbouring small numbers, those harbouring viruses are not the same as those harbouring bacteria and so on. It is not appropriate here to discuss in detail the nature of all the host's immune responses to infectious agents but it is important to appreciate the significance of $\mathrm{T}$ lymphocyte subsets and the cytokine network.

Essentially, from the moment an immunologically intact host is infected with any infectious agent, the host begins to mount an appropriate protective immune response. The key cells are the $\mathrm{Th}$ ( $\mathrm{T}$ helper) lymphocytes. At first these cells are uncommitted but they gradually differentiate into $\mathrm{Th}_{1}$ and $\mathrm{Th}_{2}$ cells, each characterized by the cytokines they produce, until eventually they become fully differentiated and, when this happens, they are mutually exclusive. The $\mathrm{Th}_{1}$ cells produce $\mathrm{T}_{1}$ cytokines, particularly IL-2 that drives the immune response towards the production of cytotoxic $\mathrm{T}\left(\mathrm{T}_{\mathrm{c}}\right)$ cells and IFN- $\gamma$ that drives the immune response towards the activation of macrophages. $\mathrm{Th}_{2}$ cells, on the other hand, produce IL-4, IL-5, IL-10 and IL13 that lead to the activation of $B$ cells and the subsequent production of antibody, and to the proliferation and differentiation of eosinophils. In shorthand, the $\mathrm{Th}_{1}$ responses represent the cellmediated arm of the immune response and the $\mathrm{Th}_{2}$ responses represent the humoral arm. For further information, there is an excellent account of this subject in Klein \& Hořejší (1997). $T_{c}$ cells are ideally suited for the destruction of virus-infected cells, IFN- $\gamma$-activated macrophages are involved in the killing of intracellular pathogens and the antibody produced by B cells is most effective against extracellular pathogens such as helminths. The role of $\mathrm{Th}_{1}$ and $\mathrm{Th}_{2}$ cells in a number of infectious diseases is well discussed in the various contributions in Romagnani (1996) and, with particular relevance to helminths, by Pritchard, Hewitt \& Moqbel (1997). Parasites are no different from other pathogens in that they inevitably induce some kind of immune response except that $T_{c}$ cells are less involved in parasitic infections than in viral infections (see Cox \& Wakelin, 1998 and Wakelin, 1996 for general accounts of the immune responses to parasites). In general, it is widely accepted that protective $\mathrm{Th}_{1}$ responses predominate in infections caused by protozoa whereas $\mathrm{Th}_{2}$ responses are more important in immunity to helminth infections. In addition, the mutual exclusivity mentioned above frequently results in extreme polarization in which one arm of the immune response is protective and the other counter protective. However, these are generalisations and the details of each individual immune response can differ from time to time or from stage to stage of an infection (Allen \& Maizels, 1997).

The polarization of $\mathrm{T}$ cells towards cell-mediated or antibody-mediated responses does not depend entirely on the infectious agent involved but can be modulated by pre-existing factors including cytokines. For example, the presence of IL-12 drives the immune response towards the $\mathrm{T}_{1}$ pole whereas the presence of IL-4 drives it towards the $\mathrm{T}_{2}$ pole (Ma $e t$ al. 1997). Initial or subsequent polarization involves the interaction of a number of regulatory cytokines some of which act as growth and differentiation factors. What is important here is that these cytokines, and also effector molecules, act non- 


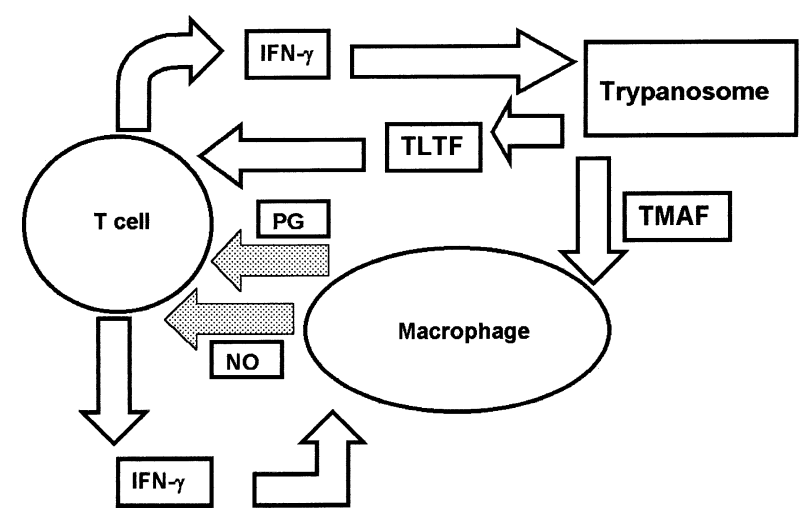

Fig. 1. Diagrammatic representation showing some of the interactions that exist between African trypanosomes and cytokine network. Trypanosomes produce a number of factors including trypanosome macrophage activating factor (TMAF) and trypanosome-derived lymphocyte triggering factor (TLTF) that stimulate macrophages and lymphocytes respectively. IFN- $\gamma$, a product of stimulated lymphocytes, can act as a trypanosome growth factor but prostaglandins (PG) and nitric oxide (NO) produced by macrophages inhibit lymphocyte activity and hence the production of IFN $-\gamma$.

Trypanosomes are therefore enmeshed in a network of cytokines and effector molecules that both stimulate and inhibit their growth and development. In this diagram, positive signals are indicated by open arrows and inhibitory ones by stippled arrows.

specifically. It is therefore possible for any infectious agent to be caught up in the cytokine network. It is now becoming clear that this is what happens in the case of any agent acquired previously, concurrently or subsequently in the majority of concomitant infections at least under controlled laboratory conditions.

EFFECTS OF CYTOKINES AND

PARASITE-DERIVED MOLECULES ON PARASITES

Although directed at other cells involved in the immune response certain molecules such as transforming growth factor-beta (TGF- $\beta$ ) and interferongamma $(\mathrm{IFN}-\gamma)$ can act directly or indirectly on parasites. For example, IFN- $\gamma$ acts as a growth factor for Trypanosoma brucei (Bakhiet et al. 1996b) and TGF- $\beta$ is required for the invasion of mammalian cells by Trypanosoma cruzi (Ming, Ewen \& Pereira, 1995). Other examples are given by Barcinski \& Costa-Moreira (1994) and Omer et al. (2000).

In addition to the molecules of the immune system, all parasites produce secreted or excreted products some of which can themselves affect cells of the immune system (see Kaye, 1999). The best studied molecules are those produced by African trypanosomes, particularly $T$. brucei brucei; trypanosome-derived lymphocyte triggering factor
(TLTF) and trypanosome macrophage activating factor (TMAF). TLTF induces lymphocytes to produce IFN- $\gamma$ which both activates macrophages and promotes trypanosome growth and TMAF also stimulates macrophage activity (see Sternberg, 1998; Hamadien, Bakhiet \& Harris, 2000). The production of TLTF is not restricted to T. $b$. brucei but has also been found in T. b. gambiense, T. b. rhodesiense and T. evansi (Bakhiet et al. 1996a). All the African trypanosomes are, therefore, potentially caught up in a series of interactions in which trypanosomederived factors activate both $\mathrm{T}$ lymphocytes and macrophages. The net effect is that lymphocyteproduced IFN- $\gamma$ enhances trypanosome growth while other trypanosome-derived molecules induce macrophages to produce molecules that inhibit lymphocyte activation (Fig. 1). Among other parasite-derived molecules there are some of protozoan origin that induce the synthesis of IL-12 by macrophages (Gazzinelli et al. 1997) and an IFN- $\gamma$ like molecule produced by the nematode Trichuris muris (Grencis \& Entwistle, 1997). The precise role of these molecules is unclear but what is important here is that these parasite-derived factors can interact with the other molecules of the immune system and may be involved in enhancing or depressing the immune response to other organisms and cannot be ignored in any consideration of concomitant infections.

INTERACTIONS BETWEEN INFECTIOUS AGENTS

There have been numerous reports of interactions between parasites and between parasites and other infectious agents (see Christensen et al. 1987). This is not intended to be a comprehensive review of the subject and many of the examples cited by Christensen et al. will not be reiterated here. However, this is an attempt to collate and categorize some examples of the various interactions that have been recorded and to try to explain them in terms of what is happening in an infected host. In this respect, the Christensen et al. paper represents the end of an era. 1986 in an important watershed in our understanding of the interactions that occur between infectious agents because it was in that year that the $\mathrm{Th}_{1} / \mathrm{Th}_{2}$ dichotomy was suggested, first in mice (Mosmann \& Coffman, 1989) then in humans (Romagnani, 1991) and subsequently in all species of mammals studied. This concept has dominated thinking about immune responses ever since (see Romagnani, 1996). Prior to this discovery, the various interactions between parasites and other infectious agents had been difficult to explain and mainly centred on attempts to implicate ill-defined mechanisms of immunodepression, often referred to as immunosuppression, brought about by molecules produced by parasites which facilitate their own 
survival. The best studied examples of immunodepression are infections with African trypanosomes (Greenwood, 1974; Hudson \& Terry, 1979), malaria parasites (Greenwood, 1974; Del Giudice, Grau \& Lambert, 1988) and nematode worms (Behnke, 1987). According to the theory of immunodepression, any concomitant infection that is acquired while the host is experiencing a phase of parasite-induced immunodepression should be able to establish itself more readily and possibly become more virulent or pathogenic. There is, for example, a correlation between the occurrence of Burkitt's lymphoma, caused by infection with the relatively harmless Epstein-Barr virus, and the presence of malaria (Burkitt, 1969). On the other hand, HIV does not seem to have much effect on malaria infections or vice versa (Butcher, 1992).

Not all factors that affect the outcome of concomitant infections are immunological. Other factors responsible for a particular outcome include changes in the microenvironment. The induction of reticulocytosis in experimental rodent malaria infections, for example, should, and does, disadvantage species such as Plasmodium vinckei and $P$. chabaudi that require mature erythrocytes resulting in lower parasitaemias. However, this explanation does not account for the fact that infections with $P$. berghei, which prefers reticulocytes, are similarly affected (see Cox, $1975 a, 1978$ and below).

These situations described above illustrate some of the problems inherent in seeking explanations for the interactions between the different agents in concomitant infections because there seem to be as many exceptions to the 'rules' as there are examples. It is, therefore, necessary to consider the nature of the possible outcomes. It is best to start with the simplest examples where a host that is harbouring, or has harboured, one organism A, is infected with a different organism, B. There are three outcomes with respect to $\mathrm{B}$ : the ensuing infection may be enhanced, suppressed or not affected in any way. However, there is also the reciprocal situation with respect to the infection caused by $\mathrm{A}$, which may also be enhanced, depressed or neutral. Thus in this simple situation, there are a number of different possible outcomes. However, this example only takes into account a subsequent infection acquired at a specific point in time during the course of the ongoing infection. The outcome of infection B may well be different if the host harbouring $\mathrm{A}$ is infected with $\mathrm{B}$ at the beginning of the infection, at its peak or during a chronic phase. For example, the outcome of dual infections with of Babesia microti and $T . b$. bruce $i$ in mice varies according to when the piroplasm is administered in relation to the trypanosome (Millott \& Cox, 1985). In this situation, the piroplasm infection is always inhibited when the trypanosome is given beforehand but the inhibition increases with the interval between the two infections until at
-21 days it is absolute (Millott \& Cox, 1985). In passing, it must be pointed out that these results are counterintuitive as it might be expected that superimposing a piroplasm infection on an ongoing trypanosome infection, during a period of what should be trypanosome-induced immunodepression, should result in higher rather than lower piroplasm infections.

There are, therefore, many different outcomes resulting from concurrent infections and, from the examples cited above, it is clear that these may be unpredictable. In searching for the truth in any complex situation it is advisable to adopt the advice of William of Ockham (or Occam) as perpetuated in the maxim, Ockham's razor, which states that in seeking an explanation, various assumptions need not be multiplied needlessly; in other words, if there is a simple explanation there is no need to seek a more complicated one. However, this implies that all the knowledge necessary to produce a feasible explanation is available but, unfortunately, it is not. Therefore, the sensible approach is to seek simple explanations wherever possible, to look for exceptions and to modify the original explanation in terms of the exceptions and new knowledge.

In the sections below, selected examples of interactions between protozoa and viruses, protozoa and bacteria, protozoa and protozoa, protozoa and helminths, helminths and viruses, helminths and bacteria and between helminths and helminths will be discussed. It must be pointed out, however, that virtually all the information available comes from carefully controlled laboratory studies, usually with mice, that are sometimes very contrived. However, it is likely that these interactions will eventually be shown to apply to natural human and animal diseases and examples of such situations will also be discussed.

\section{Protozoa and viruses}

Viral infections are usually extremely difficult to detect and, therefore, the amount of information we have on interactions between protozoa and viruses is limited. Much of what we know comes from experiments involving Plasmodium spp. and other intraerythrocytic protozoa in mice and rats but there is no coherent pattern that emerges (see the reviews by Cox, 1975a, 1978). The intensity of $P$. berghei infections is suppressed in mice infected with West Nile virus (Yoeli, Becker \& Bernkopf, 1955) or Newcastle Disease virus (Jahiel et al. 1968b) suggesting that virus-induced IFN- $\alpha$ might be protective against malaria parasites (Jahiel et al. 1968 a). However, there is no direct evidence that this is the case but, in this context, it is interesting to note that, in humans, infections with $P$. falciparum are lower in patients co-infected with measles or influenza viruses (Rooth \& Bjorkman, 1992). Thus 
viral infections may ameliorate malarial infections but, on the other hand, the non-lethal strains of $P$. yoelii and $P$. chabaudi become lethal in mice infected with the Rowson Parr virus (Cox, Wedderburn \& Salaman, 1974) and infections with the Rowson Parr or urethane leukaemia virus also enhance Babesia microti infections in mice (Cox \& Wedderburn, 1972). These results might be due to immunodepression caused by the viruses which, as a group, tend to be immunosuppressive (Salaman, 1969) but these conflict with those cited above in which infections in virally infected animals or individuals were actually suppressed.

Turning now to other combinations of protozoa and viruses (other than HIV), there are a number of observations that can be attributed to the immunodepressive effects of the virus infections and explained in terms of the consequent down regulation of cytokines required for immunity to the protozoan. Cryptosporidium parvum infections are enhanced in mice experimentally infected with the murine leukaemia retrovirus LP-BM5 (Darban et al. 1991) and this enhancement correlates with decreased IFN- $\gamma$ and IL-2 production in the virusinfected mice (Alak et al. 1993). In naturally infected chickens, infections with $C$. baileyi are enhanced in animals co-infected with the chicken anaemia virus, CAV (Hornok et al. 1998). Trypanosoma cruzi infections are also more severe in mice co-infected with viruses; for example, infections with the murine leukaemia virus, MuLV, results in the enhancement of T. cruzi infections in mice (Silva et al. 1993) and this is also the case in mice co-infected with the mouse hepatitis virus type 3 (Verinaud et al. 1998). In the MuLV-infected mice, $\mathrm{T}$ cells do not respond to trypanosome antigens, suggesting immunodepression on the part of the virus (Silva et al. 1993), and this is also the proposed explanation of the observations seen in the mouse hepatitis-infected animals (Verinaud et al. 1998).

There are very few studies on the effects of protozoan parasites on infections caused by viruses but those that have been described all indicate that viral infections are enhanced in animals harbouring parasitic protozoa. For example, infections with the murine oncogenic viruses, Murine Sarcoma virus or Moloney virus, are more severe in mice co-infected with P. yoelii (Salaman, Wedderburn \& BruceChwatt, 1969; Wedderburn, 1970, 1974) and mice co-infected with $T$. cruzi and MuLV develop a murine form of AIDS which does not occur in animals infected with either of these agents alone (Silva et al. 1993). The best documented evidence that protozoan infections can enhance viral infections in humans is that relating to the Epstein Barr virus which normally causes mild or inapparent infections but can contribute to the development of Burkitt's lymphoma in individuals exposed to malaria (see De The, 1985). Immunodepression is characteristic of malaria infections in mice and humans (McGregor \& Barr, 1962, see also Houba, 1988) and the enhancement of viral infections in co-infected animals can be explained in these terms. What is not so easy to explain, however, is the finding that the feline immunodeficiency virus (FIV) causes changes to the activity of macrophages but this does not affect coinfection with Toxoplasma gondii (Lin \& Bowman, 1992). Other interactions between $T$. gondii and immunosuppressive viruses are reviewed by Lacroix et al. (1996).

\section{Protozoa and bacteria}

Most of the information we have about interactions between protozoa and bacteria comes from studies on infections with intraerythrocytic protozoa. Early studies were mainly concerned with the spirochete, Borrelia duttoni which has little effect on infections with P. berghei (Colas-Belcour \& Vervent, 1954) and $B$. hispanica which causes a slight enhancement of $P$. berghei infections in rats (Sergent \& Poncet, 1957). As mentioned above, rickettsiae have a dramatic effect on rodent malaria infections and there is a considerable literature on the effects of Eperythrozoon coccoides and Haemobartonella muris, which both cause anaemia, and the consequent reticulocytosis that should favour the development of parasites like $P$. berghe $i$ that preferentially invade reticulocytes. In fact, the reverse is the case and $P$. berghei infections are suppressed in mice co-infected with $E$. coccoides (Peters, 1965). Infections with $P$. chabaudi and $P$. vinckei, that preferentially invade mature erythrocytes, are milder in mice harbouring $E$. coccoides which is easier to explain (Cox, 1966). Haemobartonella muris has received less attention but rats co-infected with this organism and $P$. berghei harbour higher infections of the malaria parasite than do uncontaminated controls, which is what one might expect in hosts with an increased proportion of the preferred host cells (Hsu \& Geiman, 1952; Smalley, 1975). The interactions between rickettsial infections and rodent malaria parasites are important because of serious problems inherent in interpreting results obtained in laboratory mice infected with $E$. coccoides (see Cox, 1978).

A well explored but essentially experimental aspect of the possible interactions between bacteria and protozoa arises from studies in the 1970s that demonstrated that BGC, Corynebacterium parvum and other bacteria and bacterial products protect mice against malaria parasites and piroplasms (see Cox, $1975 a$ ). In fact, the number of bacteria and bacterial products that protect mice non-specifically against blood parasites is very large (Cox, 1981) and it is very likely that, in the field, bacterial infections play an important role in modulating infections with intraerythrocytic protozoa. The most likely explanation of the protection is the production of 
mediators, probably tumor necrosis factor (TNF) and nitric oxide (NO) by macrophages. This topic is discussed more fully elsewhere in this volume by Clark.

There are very few reports of interactions between bacteria and protozoa in humans but there are a number of reports of enhanced bacterial infections, particularly in children, suffering from severe malaria. Increased prevalence and parasite densities of $P$. falciparum appear to correlate with pertussis in children in contrast to the suppression of parasitaemias seen in those suffering from viral infections mentioned above (Rooth \& Bjorkman, 1992). It is also well known that bacterial pneumonia is sometimes associated with malaria (Bygbjerg \& Lanng, 1982; Mabey, Brown \& Greenwood, 1987; Walsh et al. 2000) and there has been a report of enhanced tuberculosis in a patient with malaria (Hovette et al. 1999) but the reasons for this are not known. Given the importance of malaria it is surprising that the interactions between this disease and bacterial infections has not received much attention even in epidemiological studies (see Greenwood, 1997).

\section{Protozoa and other protozoa}

There is a massive literature concerned with the various interactions reported between protozoa and it is only possible here to draw on a few selected examples. These interactions can be divided into two main groups, interactions between parasites belonging to the same species and interactions between different species ranging from closely related to distantly related forms. The phenomenon of premunition in malaria infections has already been touched on and will not be discussed further here as it is more fully explored by Smith et al. (1999). Mixed infections with different species of malaria parasites are common (see Tanner \& Baker, 1999) and all four species that infect humans have been found in a single individual (Purnomo et al. 1999). Much of what we know about the situation in humans comes from cross-sectional surveys and these indicate the involvement of both immunological and density-dependent factors in the regulation of parasitaemias (Bruce et al. 2000). Such studies are at the descriptive stage and it is not possible to speculate on the mechanisms involved without entering into the massive literature concerned with malaria immunology. The concept of specific immunity underlies much of our understanding of the epidemiology and control of malaria infections and this assumption appeared to suffer a major setback when it was demonstrated that there was a certain degree of heterologous immunity between different species of malaria parasites in rodents (reviewed by Cox, 1978). This was later extended to the discovery of protective immunity between different genera of intraerythrocytic protozoa, Plasmodium and Babesia (Cox, H. W. \& Milar, 1968; Cox, F. E. G., 1968). Attempts were initially made to explain these findings in conventional immunological terms, such as the presence of crossreacting antigens, but it soon became clear that what happens is that the superimposed infection becomes involved in non-specific responses involving a number of mediators of inflammation, a topic that is discussed in more detail elsewhere in this supplement by Clark. Heterologous immunity is not restricted to the parasites of rodents and there is also convincing evidence that there is cross-immunity between the malaria parasites of non-human primates (Voller, Garnham \& Turner, 1966) and some evidence that infections with $P$. vivax might reduce the severity of $P$. falciparum infections in humans (Maitland, Williams \& Newbold, 1997).

In addition to the blood parasites, there are other examples of unexpected interactions between related protozoa belonging to different species. For example in mice infected with the coccidians Eimeria falciformis and E. pragensis, in that order, the cyst output of the latter is enhanced but in the reverse order there is no such effect (Shehu \& Nowell, 1998).

There are also examples of dramatic interactions between distantly related species of protozoa, the most studied being those involving trypanosomes and other blood parasites. Some of the earliest investigations were concerned with co-infections with $T$. lewisi and $P$. berghei in rats in which the parasitaemias due to both infections, particularly the trypanosomes, were enhanced (Hughes \& Tatum, 1956; Shmeul, Golensa \& Spira, 1975). Experiments in mice infected with $T$. musculi provided similar results in mice co-infected with $P$. berghei (Büngener, 1975), P. yoelii (Cox, 1975b) or Babesia microti (Cox, 1977). Trypanosoma cruzi infections are also enhanced in mice infected with $P$. berghei (Krettli, 1977). Although difficult to explain at the time, these results can now be explained in terms of immunologically significant molecules, such as IFN- $\gamma$, acting as trypanosome growth factors as has been discussed above. However, this cannot be the whole story as $T$. $b$. brucei infections are not enhanced in mice coinfected with $B$. microti whereas the babesial infections are (Millott \& Cox, 1985). In rats, infection with $T$. lewisi enhances Toxoplasma gondii infections (Guerrero, Chinchilla \& Abrahams, 1997), although the mechanism is not at all clear and could be due to immunodepression or to the effects of trypanosome-derived molecules.

There are a number of reports of reciprocal enhancements of protozoan infections in mice, for example, $P$. yoelii and Leishmania mexicana (Coleman, Edman \& Semprevivo, 1988) and P. yoelii and L. amazonensis (Coleman, Edman \& Semprevivo, 1989). $P$. berghei infections are enhanced in rats co-infected with Toxoplasma gondii 
(Rifaat et al. 1984) but there is no information about any effects on the toxoplasma infection. There are also examples of other one-sided interactions. The cyst output in mice infected with the intestinal flagellates Spironucleus muris and Giardia muris is reduced in animals also infected with $B$. microti, $P$. berghei or $P$. yoelii but the blood infections are not affected (Brett \& Cox, 1982). These authors attribute the reduction in cyst output to physiological changes in the gut rather than to any immunological factors and this also seems to apply in the case of mice coinfected with $G$. muris and Trichinella spiralis (Roberts-Thomson et al. 1976 and see below). Interactions between protozoan infections in humans are not at all easy to assess but, with the increased use of more sensitive and specific diagnostic methods, it is likely that in the future there will be a number of such reports.

\section{Protozoa and helminths}

Intuitively, it would seem unlikely that there could be any interactions between single celled protozoan and multicellular helminths, particularly as most of them occupy different sites in the body and elicit very different kinds of immune responses. In fact, in virtually all situations where protozoa and helminths occur together that have been investigated experimentally, there is some degree of interaction, sometimes very dramatic (Christensen et al. 1987; Chieffi, 1992; Petney \& Andrews, 1998; see Behnke et al. this supplement) Some of these interactions are now beginning to be subjected to the kind of analysis involving $\mathrm{Th}_{1}$ and $\mathrm{Th}_{2}$ cells referred to at the beginning of this review and this topic is discussed elsewhere in this supplement with relevance to nematode worms in rodents (see paper by Behnke et $a l$.). The most studied interactions are those between trypanosomes and the intestinal nematode worm Trichinella spiralis. Mice infected with T. spiralis experience considerably increased Trypanosoma musculi infections when the nematode infection is initiated 5-10 days before the trypanosome and this enhancement is still obvious after 45 days (Bell, Adams \& Ogden, 1984a). Similar enhancement of the trypanosome infection occurs in strains of mice differing in resistance to $T$. spiralis suggesting that this phenomenon is a general one that overrides the inherent susceptibility or resistance to the nematode (Chiejna \& Wakelin, 1984). There are also reciprocal effects and the expulsion of T. spiralis is inhibited by infections with $T$. musculi also indicating a suppressive effect on the host's immune response, this time in the other direction (Bell, Adams \& Ogden, $1984 b$ ). Thus it would seem that, in this model of doubly-infected animals, both the trypanosome and the nematode benefit although the details of the actual outcome vary from strain to strain of mouse. However the trypanosome also reduces the fecundity of the worms which, therefore, suffer from the relationship in a different way (Bell, Adams \& Ogden, 1984b). Rats infected with T. b. brucei also fail to expel the nematode worm Nippostrongylus brasiliensis (Urquhart et al. 1973), as is the case in another combination of trypanosome and nematode, T. b. bruce $i$ and Trichinella spiralis, in mice where the presence of the trypanosome also has an inhibitory effect on immunity to the worm (Onah \& Wakelin, 1999). These authors measured IFN- $\gamma$ and IL-4 levels, markers for $\mathrm{Th}_{1}$ and $\mathrm{Th}_{2}$ responses respectively and found that in the doubly-infected animals levels of IFN- $\gamma$ were increased and levels of IL-4 were reduced and they conclude that in the doublyinfected animals the immune response is biased to the $\mathrm{T}_{1}$ pole thus inhibiting immunity to $T$. spiralis which relies on the activation of $\mathrm{T}_{2}$ responses.

The findings that trypanosome infections are enhanced in animals co-infected with nematodes relate to laboratory systems but there is some evidence that in domesticated animals the outcome is likely to be similar. In a natural situation, N'dama cattle in The Gambia are more susceptible to infection with $T$. congolense or $T$. vivax if they are infected with trichostongyle nematodes (Dwinger $e t$ al. 1994) and sheep infected with Haemonchus contortus and T. congolense are able to tolerate either infection but not both (Goossens et al. 1997). However, it is impossible to generalise from these findings and those discussed above and conclude that in dual infections with nematodes and trypanosomes the trypanosome infection will always be enhanced. For example in mice infected with Heligmosomoides polygyrus and T. musculi the trypanosome infection is not enhanced (Bell, Adams \& Ogden, 1984a).

Schistosome infections interact with a variety of protozoa, at least in experimental models (see Chieffi, 1992). Infections with the rodent malaria parasites are affected in different ways by the presence of Schistosoma mansoni. For example, in the vole Microtus guentheri, P. berghei infections are enhanced if the two infections are given within 2 weeks of each other but depressed if the malaria infection is given seven weeks after the schistosome infection when the immune response to the worm is most active (Yoeli, 1956). There are also reciprocal interactions and $P$. yoelii actually inhibits the development of schistosome granulomas in experimentally infected mice (Abdel-Wahab et al. 1974). There have been some attempts to explain the complex and interdependent interactions between schistosomes and malaria parasites in terms of the $\mathrm{Th}_{1} / \mathrm{Th}_{2}$ dichotomy. In mice infected with $S$. mansoni, infections with the malaria parasite $P$. chabaudi are enhanced in animals infected with the worm 8 weeks previously while $\mathrm{Th}_{2}$ responses to soluble egg antigens are reduced for 4 weeks after the malaria infection (Helmby, Kullberg \& Troye-Blomberg, 1998), a finding that also applies in other situations that will be discussed below. 
Schistosomes also interact with a number of other protozoa and infections with $T$. cruzi are much more severe in mice previously infected with $S$. mansoni (Kloetzel, Faleiros \& Mendes, 1971) as are infections with Toxoplasma gondii (Kloetzel et al. 1977). Schistosoma mansoni-infected mice also experience more intense infections with the intestinal protozoa Entamoeba muris, Trichomonas muris and Spironucleus muris (Higgins-Opitz et al. 1990) but not Leishmania major (Yoshida et al. 1999) although L. infantum infections are more severe in hamsters infected with S. mansoni (Mangoud et al. 1998). Turning to the effect of protozoa and schistosome infections, L. infantum in hamsters delays $S$. mansoni granuloma formation (Morsy et al. 1998), a finding similar to that recorded for malaria parasites discussed above although when mice infected with $S$. mansoni, and undergoing an ongoing $\mathrm{Th}_{2}$-inducing infection, are infected with Toxoplasma gondii, an infection that is responsive to $\mathrm{Th}_{1}$ cytokines, there is a considerable reduction in schistosome granuloma size but there is no evidence of uncontrolled toxoplasma replication (Marshall et al. 1999). Taken together, these results suggest that infections with protozoa that stimulate a $T h_{1}$ response actually downregulate $\mathrm{Th}_{2}$ responses with the result that the development of schistosome granulomas, a $\mathrm{Th}_{2}$ phenomenon, is inhibited.

There is some indication that schistosomes interact with protozoa in the field and, from epidemiological studies in Egypt, it appears that the schistosomes interfere with the acquisition of immunity to Entamoeba histolytica and/or E. dispar (Mansour et al. 1997).

The expulsion of nematode infections is inhibited in mice infected with blood parasites, for example in mice infected with B. microti or B. hylomysci and Trichuris muris the expulsion of the worm is delayed, the suggested explanation being the immunodepression induced by the piroplasms (Phillips \& Wakelin, 1976) and mice infected with Plasmodium berghei suffer from prolonged infections with Nippostrongylus brasiliensis and the self-cure mechanism is suppressed (Modrić \& Mayberry, 1994). These authors attribute the results to decreased eosinophil production in the doubly-infected mice. Infections with intraerythrocytic protozoa, therefore, have an adverse effect on concomitant nematode infections. On the other hand, B. microti infections are not enhanced or prolonged in mice co-infected with Heligmosomoides polygyrus (Behnke, Sinski \& Wakelin, 1999).

Among other records of interactions between protozoa and helminths is the observation that infections of Entamoeba histolytica are enhanced in mice infected with Syphacla obvelata (Vinayak \& Chopra, 1978). There have been conflicting results from studies involving T. spiralis and Eimeria spp. In one study in mice, the outcome of infections with
T. spiralis and E. vermiformis or E. pragensis differed according to the eimerian species; E. vermiformis delayed the expulsion of the worm whereas $E$. pragensis did not and the replication of $E$. vermiformis was enhanced in the presence of the worm whereas that of E. pragensis was reduced (Rose, Wakelin \& Hesketh, 1994). These authors explain the results in terms of inflammation and immunological responses. In rats infected with $T$. spiralis and $E$. nieschulzi there were decreases in the number of adult worms and muscle parasitism and also in the numbers of oocysts produced by the protozoan (Stewart, Reddington \& Hamilton, 1980). It is possible to interpret these last results in terms of changes to the architecture of the gut as the worms reach the gut when it has been severely damaged by the eimerian. A number of other examples of interactions between T. spiralis and Eimeria spp. are cited and discussed by Rose et al. (1994) who conclude that it is not possible to predict the outcome of the interactions between these parasites. Staying with intestinal infections and another combination involving $T$. spiralis and the intestinal flagellate, Giardia muris, the output of protozoan cysts is decreased in doublyinfected mice but the worm infection is not affected (Roberts-Thomson et al. 1976). The authors attribute this decrease in cyst output to changes in the gut rather than to any immunological factors, a conclusion also reached in the experiments using $G$. muris and the intraerythrocytic protozoa mentioned above (Brett \& Cox, 1982).

Among other interesting interactions between helminths and protozoa are those between Taenia crassiceps and T. cruzi where, if the two are given to mice together, there is a slight delay in the onset of the trypanosome parasitaemia whereas if the trypanosome infection is initiated later during the cestode infection there are decreases in the levels of both IFN- $\gamma$ and IL-4 and susceptibility to the trypanosome infection is markedly enhanced. In mice infected with $T$. spiralis and L. infantum 7 days later, when IFN- $\gamma$ levels are already elevated, the subsequent leishmania infection is milder and the parasite load is reduced (Rousseau et al. 1997) and in mice infected with T. spiralis and T. gondii, also 7 days later, the protozoan infection is also milder (Afifi et al. 1999). In these experiments infection with $T$. gondii also protects against the nematode.

\section{Helminths and viruses}

Although concurrent infections of helminths and viruses are common the literature on the subject is rather limited and it is interesting to note that there are very few reports on the effects of immunosuppressive viruses on the outcome of helminth infections (see Markell, John \& Krotoski, 1999). The best studied examples are those of the human 
lymphotropic virus type 1 (HTVL-1) that enhances infections with Strongyloides stercoralis (see Genta \& Walzer, 1989). There is little evidence to suggest that HIV and schistosomes interact with one another despite the fact that they occur together in many parts of the world. However, there is some evidence that human infections with the hepatitis B virus contribute to liver damage caused by $S$. mansoni (Strauss \& Lacet, 1986). There is also evidence that the viral infection is actually enhanced by the presence of the schistosomes and that there is an association between hepatitis B and the severity of schistosomiasis in Brazil (Strauss \& Lacet, 1986) and Egypt (Madwar, El Tahawy \& Strickland, 1989). Taken together, these findings indicate that infections with helminths can increase the severity of viral infections.

\section{Helminths and bacteria}

Some of the earliest reports of interactions between bacteria and helminths are concerned with a phenomenon called 'prolonged septicemic salmonellosis' in which patients infected with $S$. mansoni experienced prolonged bacteraemias due to several species of Salmonella. This finding was subsequently extended to other bacteria and the term 'prolonged septicaemic enterobacteriosis' was coined for this condition (see Chieffi, 1992). It has been suggested that this phenomenon is due either to immunodepression induced by the schistosomes or by the provision of some sort of protection to the bacteria (see Chieffi, 1992). There are, however, interactions between Escherichia coli toxins and schistosomes in mice in which the lethality caused by both agents is increased (see Chieffi, 1992). Much of the current interest in the effects of bacterial infections on helminths is indirect and is concerned with what happens in individuals vaccinated against $M y c o-$ bacterium tuberculosis, the causative agent of tuberculosis, with BCG, particularly the purified protein derivative (PPD). BCG stimulates $\mathrm{Th}_{1}$ immune responses and there is some concern that this might bias the response away from protection which, in the case of the helminths, tends to be $\mathrm{Th}_{2}$ dependent. In fact, there is no evidence that this happens but there is evidence that the reverse is the case and in children sensitized in utero with $S$. haematobium or Wuchereria bancroft $i$ the bias is away from the $\mathrm{Th}_{1}$ responses required for protection against mycobacterial infections (Malhotra et al. 1999). Similarly, there is evidence that infection with Onchocerca volvulus may have an inhibitory effect on the immune responses to $M$. tuberculosis or $M$. leprae, the causative agent of leprosy (Stewart et al. 1999). These authors also comment on the significance of these findings with reference to reports of increased incidences of lepromatous leprosy in individuals with onchocerciasis. Fasciola hepatica is another helminth that suppresses the protective $\mathrm{Th}_{1}$ immune response against a bacterial infection, in this case Bordetella pertussis (Brady et al. 1999). It would appear from these examples that helminth infections that induce protective $\mathrm{Th}_{2}$ immune responses can also downregulate $\mathrm{Th}_{1}$ responses and that this might bring about the exacerbation of concomitant infections or a failure to respond to vaccination in infections that are controlled by $\mathrm{Th}_{1}$ responses.

\section{Helminths and other helminths}

There are numerous examples of interactions between helminth worms (see Christensen et al. 1987) and those involving nematodes of rodents are discussed elsewhere in this supplement by Behnke and others. The best studied example of interactions between helminths is the phenomenon of concomitant immunity in which the adults of an ongoing infection prevent the establishment of another infection with larvae of the same species by eliciting an immune response which the adult worms can evade but the new larvae cannot. This seems to be a common phenomenon in helminth infections and is best exemplified by schistosomes (Smithers, Terry \& Hockley, 1969) and by Echinococcus granulosus (see Heath, 1995). These interactions between worms belonging to the same species will not be discussed further here. Different species of helminth do, however, frequently occur in the same host and can interact with one another. The ecological aspects of such concurrent infections are discussed elsewhere in this supplement by Poulin and some of the immunological aspects of interactions between nematode worms are discussed by Behnke and his colleagues. It is only possible to discuss a few examples of different kinds of interactions here. In mice concurrently infected with the nematodes Trichuris muris and Heligmosomoides polygyrus the trichurid infection is rejected more slowly than in animals harbouring this parasite alone and the authors consider that this is due to a raising of the immune threshold necessary for the expulsion of the worms (Behnke, Ali \& Jenkins, 1984). However, in most other systems investigated, the superimposed infection is suppressed by the presence of the original agent. In mice infected with $S$. mansoni and the cestode Mesocestoides corti, there is a reduction in the number of $M$. corti tetrathyridia and in the intensity of infection in the animals harbouring dual infections (Chernin et al. 1988). In mice infected with $S$. mansoni and the cestodes Hymenolepis diminuta or Rodentolepis microstoma there is an accelerated expulsion of the cestodes (Andreassen, Odaibo \& Christensen, 1990). In mice co-infected with $S$. mansoni and T. muris, the $\mathrm{Th}_{2}$ response to schistosome eggs appears to be involved in the elimination of the nematode infection (Curry et al. 1995) and in 
mice infected with S. mansoni and Strongyloides venezuelensis there is a decrease in the numbers of the nematode which the authors attribute to the effects of the immune response on the migrating larvae (Yoshida et al. 1999). There is also evidence from the field that infection with $S$. mansoni is in some way protective against infection with the geohelminths Ascaris lumbricoides, Trichuris trichiura and hookworms (Chamone et al. 1990). Thus, from these few examples it is clear that, in most combinations, infection with one worm can protect against others but that there are some circumstances in which infection with one helminth can enhance infection with another. Dual infections may also have synergistic effects on the pathology of some infections, for example children co-infected with hookworms and Trichuris trichiura have significantly less haemoglobin than children harbouring only one of these nematodes (Robertson et al. 1992).

DISCUSSION

This review, which of necessity is very selective, is intended to indicate the range of interactions between infectious agents that might affect the outcome of parasitic infections. It should be clear that mixed infections are the rule in natural situations and that protozoan infections are affected by other protozoa, helminths, bacteria and viruses while helminth infections are affected by protozoa, bacteria, viruses and other helminths. In virtually every combination that has been examined one or other of the concomitant agents is affected by the presence of the other and in many cases both are affected. In addition to these infectious agents, there are also fungi and prions to consider and virtually nothing is known about how these interact with parasites. The outcome of any interaction is not necessarily predictable and can vary from stage to stage of the infection. The age and sex of the host, factors that have not been considered here, can also influence the outcome of an infection. The important thing to be borne in mind is that these interactions do occur and cannot be ignored.

\section{Immunodepression}

The most common outcomes in dual infections are that the infection caused by one or other of the agents may be enhanced or depressed, both may be affected, one may be enhanced and the other depressed or vice versa. In addition, the presence of one agent can increase or decrease the severity of the pathology caused by the other. With all these possibilities the outcomes of any combination might be unpredictable but there are a number of patterns that seem to be consistent and a beginning has been made in unravelling these patterns. The most common situation is one in which one agent causes immunodepression and a superimposed infection is able to take advantage of this situation. Essentially this is no different from the situation in which many immunocompromised hosts are susceptible to intercurrent infections with a range of microorganisms. However, it is too simplistic to assume that any parasitic infection in an immunocompromised host is likely to be enhanced and, in this context, it is interesting to note that very few parasitic infections are actually significantly enhanced in individuals infected with HIV (see Ambroise-Thomas, in this volume). Some degree of immunodepression is common, if not universal, during the course of infections with parasites and microorganisms but the methods used to assess the immune status of the host need not necessarily reveal those aspects that are relevant to the superimposed infection. For example, many of the early observations on immunodepression in parasitic infections were based on counting antibody-producing cells, which is no longer appropriate given our present knowledge of the roles of $\mathrm{T}$ cells in immune responses. Immunodepression during parasitic infections may be due to by-products of an ongoing protective immune response or to factors induced by the parasites themselves in order to ensure their own survival or to damp down immunopathological changes. Various aspects of these processes are discussed in more detail in the various contributions in Doenhoff \& Chappell (1997). What is important to understand here is what the essential elements of a particular immune response are that render the host more or less susceptible to infection. There may be other alternatives to explain the enhanced infections seen during concomitant infections such as factors that enhance the growth or development of the parasite produced as part of the normal immune response or alterations to the cells required for the survival of a particular parasite.

\section{The $T h_{1} / T h_{2}$ dichotomy}

The second important factor in determining the outcome of an infection is whether or not the established infection is inducing a $\mathrm{Th}_{1}$ or a $\mathrm{Th}_{2}$ response. The $T h_{1}$ immunological milieu involves a number of molecules and the cells that produce them, in particular, NK cells, IL-12 and IFN- $\gamma$. The initiation of a new immune response in such a situation is gradually forced towards the $T h_{1}$ pole and, if the superimposed agent is controlled by $\mathrm{Th}_{2}$ responses, it is at an advantage in such a situation. The reverse applies if IL-4 predominates in the immunological milieu at the time of the second infection. There is now a considerable amount of solid work going on in this area and from the experiments that have been described it looks as if the pattern described above is of general application. However, it is important to bear in mind that the 
$\mathrm{Th}_{1} / \mathrm{Th}_{2}$ paradigm is not a rigid set of rules (Allen $\&$ Maizels, 1997) and that there may be switches in the patterns of $\mathrm{Th}_{1}$ and $\mathrm{Th}_{2}$ cytokines during the course of an infection as has been clearly demonstrated in the case of rodent malarias (Taylor-Robinson \& Phillips, 1998).

\section{Immune effector molecules}

A number of molecules involved in the immune response act on a variety of cells and can affect parasites directly. Mention has already been made of IFN- $\alpha$ which, although important in viral infections, does not seem to play any significant part in the immune responses induced by, or otherwise involved in, parasitic infections. There are, however, a number of molecules that are relevant, the most studied being the lymphocyte product, IFN- $\gamma$, and the macrophage products TNF, TGF $-\beta$, NO and reactive oxygen intermediates. Regardless of how a particular immune response was initiated these molecules act non-specifically and thus a superimposed parasite may be affected by effector molecules the production of which it itself has not initiated, in other words, the bystander effect.

\section{Parasite-derived immunomodulatory factors}

It is now clear that a number of parasites produce molecules that affect cells of the immune response directly or indirectly and thus exert immunomodulatory effects. The best characterized are trypanosome macrophage activating factor (TMAF) and trypanosome lymphocyte triggering factor (TLTF) and it is almost certain that a number of others will be described. The presence and effects of such molecules will have to be taken into account when considering concomitant infections.

\section{The significance of studies on concomitant infections}

It has been the purpose of this review to give some indication of the range of interactions that occur when a host is infected with more than one infectious agent. These interactions cover the whole spectrum from the enhancement to suppression of one or other or both of the co-infecting agents and from the augmentation to the amelioration of the pathology of the infection. This means that the nature of any specific parasitic infection in a host concurrently infected with another infectious agent may be very different from an infection caused by the same parasite in a host co-infected with another agent or in a host that is otherwise uninfected. This has a number of implications that relate to the epidemiological and clinical aspects of human and veterinary parasitology and to the development of vaccines and the use of chemotherapy. The best known example of the clinical implications of interacting infections is Burkitt's lymphoma, resulting from an interaction between the Epstein-Barr virus and malaria (Burkitt, 1969; De The, 1985) where the host appears to lose the $\mathrm{T}$ cell control of the virus infection (Whittle et al. 1984). There are also other examples including the increased incidence of lepromatous leprosy in patients with onchocerciasis (Stewart et al. 1999) and more severe strongyloidiasis in patients harbouring the virus HTVL-1 (Genta \& Walzer, 1989). There is now a vast amount of evidence from experimental studies to suggest that the clinical picture in many infections may be markedly influenced by the presence of unrelated organisms and it is probable that such influences will prove to be the rule rather than the exception.

Concomitant infections are also likely to affect the efficacy of vaccines and will influence the design of new vaccines. It is already known that it is difficult to vaccinate children with malaria against tetanus, typhoid or bacterial meningococcus (Williamson \& Greenwood, 1978, and see Björkman, 1988). Children sensitized to helminth antigens also appear to have an impaired response to mycobacterial antigens (Malhotra et al. 1999). New antiparasitic vaccines will have to take account of the possibility of inhibiting the immune responses to antimicrobial and antiviral vaccines by triggering inappropriate immune responses. Such inappropriate responses might also result from chemotherapy which causes the death of the parasites and the release of sequestered antigens as occurs in some autoimmune diseases. It has been suggested that new antiparasitic vaccines should be designed to trigger the appropriate $T_{1}$ or $T_{2}$ response (Cox, 1997) but care will also have to be taken to ensure that the efficacy of such vaccines is not impaired by concomitant infections.

Concomitant infections have long been ignored by parasitologists but the time has now come to accept that such infections may be the rule and not the exception and to test laboratory findings in the field. Our understanding of the totality of the immune response, particularly its cytokine control, has now provided us with tools to analyse what is happening during the course of mixed infections and it would be remiss of us not to take advantage of these tools and to apply the findings to the rational control of parasitic infections in animals and humans.

\section{REFERENCES}

ABDEL-WAHAB, M. F., POWERS, K. G., MAHMOUd, S. S. \& GOOD, W. C. (1974). Suppression of schistosome granuloma formation by malaria in mice. American Fournal of Tropical Medicine and Hygiene 23, 915-918. Afifi, M. A., El-Hoseiny, L. M., MOUStafa, M. A., Gamra, M. M. \& KHALIFA, K. E. (1999). Reciprocal heterologous protection between Trichinella spiralis and Toxoplasma gondii concurrently present in experimental murine models. Fournal of the Egyptian Society of Parasitology 29, 963-978. 
ALAK, J. I., SHAHBAZIAN, M., HUANG, D. S., WANG, Y., DARBAN, H., JENKINS, E. M. \& WATSON, R. R. (1993). Alcohol and murine immunodeficiency syndrome suppression of Cryptosporidium parvum infection during modulation of cytokine production. Alcohol Clinical and Experimental Research 17, 539-544.

ALlEN, J. E. \& MAIZELS, R. M. (1997). Th1-Th2: reliable paradigm or dangerous dogma? Immunology Today 18, 387-392.

ANDERSON, R. M. (1994). Populations, infectious disease and immunity: a very nonlinear world. Philosophical Transactions of the Royal Society, Section B 346, 457-505.

ANDERSON, R. M. \& MAY, R. M. (1991). Infectious Diseases of Humans. Dynamics and Control. Oxford: Oxford University Press.

ANDREASSEN, J., ODAibo, A. B. \& CHRISTENSEN, N. ø. (1990). Antagonistic effects of Schistosoma mansoni on superimposed Hymenolepis diminuta and $H$. microstoma infections in mice. Fournal of Helminthology 64, 337-339.

ASHFORD, R. W. (1991). The human parasite fauna: towards an analysis and interpretation. Annals of Tropical Medicine and Parasitology 85, 189-198.

BAKHIET, M., BÜSCHER, P., HARRIS, R. A., KRISTENSSON, K., Wigzell, H. \& OLSSON, T. (1996 $a$ ). Different Trypanozoon species possess CD8 dependent lymphocyte triggering factor-like activity. Immunology Letters 50, 71-80.

BAKHIET, M., OLSSON, T., MHLANGa, P., BÜSCHER, P., LYCKE, N., VAN DER MEIDE, P. H. \& KRISTENSSON, K. $(1996 b)$. Human and rodent interferon-gamma as a growth factor for Trypanosoma brucei. European Fournal of Immunology 26, 1359-1364.

BARCinski, M. A. \& COSTA-MOREIRA, M. E. (1994). Cellular responses of protozoan parasites to host-derived cytokines. Parasitology Today 10, 352-355.

Barnard, C. J. \& BeHnke, J. M. (eds) (1990). Parasitism and Host Behaviour. London: Taylor and Francis.

Beckage, N. E. (ed.) (1997). Parasites and Pathogens. Effects on Host Hormones and Behavior. New York: International Thomson Publishing.

BEHNKE, J. M. (1987). Evasion of immunity by nematode parasites causing chronic infections. Advances in Parasitology 26, 1-71.

BEHNKe, J. M., ALI, N. M. \& JENKINS, S. N. (1984). Survival to patency of low level infections with Trichuris muris in mice concurrently infected with Nematospiroides dubius. Annals of Tropical Medicine and Parasitology 78, 509-517.

BeHNKe, J. M., SINSKi, E. \& WAKELIN, D. (1999). Primary infections with Babesia microti are not prolonged by concurrent Heligmosomoides polygyrus. Parasitology International 48, 183-187.

BELL, R. G., ADAMS, L. S. \& OGDEN, R. W. (1984a). Trypanosoma musculi with Trichinella spiralis or Heligmosomoides polygyrus: concomitant infections in the mouse. Experimental Parasitology 58, 8-18.

BELL, R. G., ADAMS, L. S. \& OGDEN, R. W. (1984 b). Trypanosoma musculi and Trichinella spiralis: concomitant infections and selection for resistance genotypes in mice. Experimental Parasitology 58, 19-26.

BJÖRKMAN, A. (1988). Interactions between chemotherapy and immunity to malaria. In Malaria Immunology (ed. Perlmann, P. \& Wigzell, H). Progress in Allergy 41, 331-356.

BRADy, M. T., O'NeIll, S. M., DALTON, J. P. \& Mills, K. H. (1999). Fasciola hepatica suppresses a protective $\mathrm{Th}_{1}$ response against Bordetella pertussis. Infection and Immunity 67, 5372-5378.

BRETT, S. J. \& COX, F. E. G. (1982). Interactions between the intestinal flagellates Giardia muris and Spironucleus muris and the blood parasites Babesia microti, Plasmodium yoelii and Plasmodium berghei in mice. Parasitology 85, 101-110.

BRooks, D. R. \& Mclennan, D. A. (1993). Parascript. Parasites and the Language of Evolution. Washington: Smithsonian Institution Press.

BRothwell, D. \& SANDison, A. T. (eds) (1967). Diseases in Antiquity. Springfield, Illinois: C. T. Thomas.

BRUCE, M. C., DONNELly, C. A., ALPERS, M. P., GALINSKI, M. R., BARNWELl, J. W., WALlikeR, D. \& DAY, K. P. (2000). Cross-species interactions between malaria parasites in humans. Science 287, 845-848.

BÜNGENER, w. (1975). Verlauf von Trypanosoma musculiInfektion in mit Plasmodium berghei infizierten Mäusen. Zeitschrift für Tropemedizin und Parasitologie 26, 285-290.

BURKITT, D. P. (1969). Etiology of Burkitt's lymphoma - an alternative hypothesis to a vectored virus. Fournal of the National Cancer Institute $\mathbf{4 2}$, 19-28.

BUTCHER, G. A. (1992). HIV and malaria: a lesson in immunology. Parasitology Today 8, 307-311.

BYGBJERG, I. C. \& LANNG, C. (1982). Septicaemia as complication of falciparum malaria. Transactions of the Royal Society of Tropical Medicine and Hygiene 76, 705 .

Chamone, M., Marques, C. A., Atuncar, G. S. \& Pereira, A. L. A. (1990). Are there interactions between schistosomes and intestinal nematodes? Transactions of the Royal Society of Tropical Medicine and Hygiene 84, 557-558.

CHERNin, J., McLaREN, D. J., MORINAN, A. \& JAMIESON, B. N. (1988). Mesocestoides corti: parameters of infection in CBA/Ca mice and the effects of introducing a concomitant trematode infection. Parasitology 97, 393-402.

CHIEFFI, P. P. (1992). Interrelationship between schistosomiasis and concomitant disease. Memórias do Instituto Oswaldo Cruz 87, 291-296.

CHIEJINA, s. N. \& WAKELIN, D. (1984). Interactions between infections with blood protozoa and gastrointestinal nematodes. Helminthologia 31, 17-21.

CHRISTENSEN, N. Ø., NANSEN, P., FAGBEMI, B. O. \& MONRAD, J. (1987). Heterologous antagonistic and synergistic interactions between helminths and between helminths and protozoans in concurrent experimental infection of mammalian hosts.

Parasitology Research 73, 387-410.

COCKBURn, A., COCKBURn, E. \& REYMAn, T. A. (eds) (1998). Mummies, Disease and Ancient Cultures. 2nd edn. Cambridge: Cambridge University Press.

Colas-Belcour, J. \& Vervent, G. (1954). Sur des infections mixtes de la souris à spirochétes récurrents et Plasmodium berghei. Bulletin de la Société de Pathologie Exotique 47, 493-497. 
COlEMAN, R. E., EDMAN, J. D. \& SEMPREVivo, L. H. (1988). Leishmania mexicana: effect of concomitant malaria on cutaneous leishmaniasis. Development of lesions in a Leishmania-susceptible (BALB/c) strain of mouse. Experimental Parasitology 65, 269-276.

COleman, R. E., EDMAN, J. D. \& SEMPRevivo, L. H. (1989). The effect of pentostam and cimetidine on the development of leishmaniasis (Leishmania mexicana amazonensis) and concomitant malaria (Plasmodium yoelii). Annals of Tropical Medicine and Parasitology 83, 339-344.

Cox, F. E. G. (1966). Acquired immunity to Plasmodium vinckei in mice. Parasitology 56, 719-732.

COX, F. E. G. (1968). Immunity to malaria after recovery from piroplasmosis in mice. Nature 219, 646.

COX, F. E. G. $(1975 a)$. Factors affecting infections of mammals with intraerythrocytic protozoa. Symposia of the British Society for Experimental Biology 29, 429-451.

cox, F. E. G. (1975 b). Enhanced Trypanosoma musculi infections in mice with concomitant malaria. Nature 258, 148-149.

Cox, F. E. G. (1977). Interactions between trypanosomes and piroplasms in mice. Protozoology 3, 129-134.

Cox, F. E. G. (1978). Concomitant infections. In Rodent Malaria (ed. Killick-Kendrick, R. \& Peters, W.), pp. 309-342. London: Academic Press.

COX, F. E. G. (1981). Non-specific immunization against parasites. In Isotopes and Radiation in Parasitology IV, pp. 91-100. Vienna: International Atomic Energy Agency.

COX, F. E. G. (1997). Designer vaccines for parasitic diseases. International Fournal for Parasitology 27, 1147-1157.

COX, F. E. G. \& WAKELIN, D. (1998). Immunology and immunopathology of human parasitic infections. In Topley and Wilson's Microbiology and Microbial Infections, 9th edn. Volume 5, Parasitology (ed. Cox, F. E. G., Kreier, J. P. \& Wakelin, D.), pp. 57-84. London: Arnold.

COX, F. E. G. \& WEDDERBURN, N. (1972). Enhancement and prolongation of Babesia microti infections in mice infected with oncogenic viruses. Fournal of General Microbiology 72, 79-85.

COX, F. E. G., WEDDERbURN, N. \& SAlAMAN, M. H. (1974). The effect of Rowson-Parr Virus on the severity of malaria in mice. Fournal of General Microbiology 85, 358-364.

COX, H. W. \& MILAR, R. (1968). Cross-protection immunization of Plasmodium and Babesia infections of rats and mice. American Fournal of Tropical Medicine and Hygiene 17, 173-179.

CURRY, A. J., ELSE, K. J., JONES, F., BANCROFT, A., GRENCIS, R. K. \& DUNNE, D. W. (1995). Evidence that cytokinemediated immune interactions induced by Schistosoma mansoni alter disease outcome in mice concurrently infected with Trichuris muris. Fournal of Experimental Medicine 181, 769-774.

DARban, H., ENRIQUeZ, J., STERling, C. R., LOPEZ, M. C., CHEN, G., ABbaszadegan, M. \& WATSON, R. R. (1991). Cryptosporidiosis facilitated by retroviral infection with LP-BM5. Fournal of Infectious Diseases 164, 741-745.
DEL GiUdice, G., GRAU, G. E. \& LAMBert, R. H. (1988). Host responsiveness to malaria epitopes and immunopathology. In Malaria Immunology (ed. Perlmann, P. \& Wigzell, H). Progress in Allergy 41, 288-330.

De THE, G. (1985). Epstein-Barr virus and Burkitt's lymphoma worldwide; the causal relationship revisited. In Burkitt's Lymphoma: A Human Cancer Model (ed. Lenoir, G. M., O’Conor, G. T. \& Olweny, C. L. M.), pp. 165-176. Lyon: IARC Scientific Publications No. 60.

DOBSON, A. P. (1985). The population dynamics of competition between parasites. Parasitology 91, 317-347.

DoBson, A. P. (1990). Models for multi-species parasitehost communities. In Parasite Communities. Patterns and Processes (ed. Esch, G., Bush, A. \& Aho, J.), pp. 261-288. London: Chapman and Hall.

DOENHOFF, M. J. \& CHAPPELL, L. H. (eds) (1997). Survival of parasites, microbes and tumours: strategies for evasion, manipulation and exploitation of the immune response. Parasitology 115 (Suppl.). S1-S175.

DWINGER, R. H., AGYEMANG, K., KAUFMANN, J., GRIEVE, A. S. \& BAH, M. L. (1994). Effects of trypanosome and helminth infections on health and production parameters of village N'Dama cattle in the Gambia. Veterinary Parasitology 54, 353-365.

GAZZINELli, R. T., CAMARGO, M. M., ALMEIDA, I. C., MORITA, Y. S., GIRALDO, M., ACOSTA-SERRANO, A., HEINY, S., ENGLund, P. T., FERGuson, M. A. J., Travassos, L. R. \& SHER, A. (1997). Identification and characterization of protozoan products that trigger the synthesis of IL12 by inflammatory macrophages. In $I L-12$. (ed. Aldorini, A.), Chemical Immunology 68, 136-152. Basel: Karger.

GENTA, R. M. \& WALZER, P. D. (1989). Strongyloidiasis. In Parasitic Infections in the Compromised Host (ed. Walzer, P. D. \& Genta, R. M.), pp. 463-525. New York: Marcel Dekker.

GOOSSENS, B., OSAER, S., KORA, S., JAINTER, J., NDAO, M. \& GEERTs, s. (1997). The interaction of Trypanosoma congolense and Haemonchus contortus in Djallonké sheep. International Fournal for Parasitology 27, 1579-1584.

GREENWOOD, B. M. (1974). Immunosuppression in malaria and trypanosomiasis. In Parasites in the Immunized Host : Mechanisms of Survival. Ciba Foundation Symposium No. 25 (new series), pp. 137-146. Amsterdam: Elsevier.

GREENwOOD, B. M. (1997). The epidemiology of malaria. Annals of Tropical Medicine and Parasitology 91, 763-769.

GRENCIS, R. K. \& ENTWISTLE, G. M. (1997). Production of an interferon-gamma homologue by an intestinal nematode: functionally significant or interesting artefact? Parasitology 115, S101-S105.

GRENFELl, B. T. \& DOBSON, A. P. (eds) (1995). Ecology of Infectious Diseases in Natural Populations. Cambridge: Cambridge University Press.

GUerrero, O. M., CHinchilla, M. \& abrahams, E. (1997). Increasing of Toxoplasma gondii (Coccidia Sarcocystidae) infections by Trypanosoma lewisi (Kinetoplastida, Trypanosomatidae) in white rats. Revista de Biologia Tropical 45, 877-888. 
HAMADIEN, M., BAKHIET, M. \& HARRIS, R. A. (2000). Interferon- $\gamma$ induces secretion of trypanosome lymphocyte triggering factor via tyrosine protein kinases. Parasitology 120, 281-287.

HEATH, D. D. (1995). Immunology of Echinococcus infections. In Echinococcus and Hydatid Disease (ed. Thompson, R. C. A. \& Lymbery, A. J.) pp. 183-200. Wallingford, Oxford: CAB International.

Helmby, H., KullberG, M. \& TROYE-BlomberG, M. (1998). Altered immune responses in mice with concomitant Schistosoma mansoni and Plasmodium chabaudi infections. Infection and Immunity 66, 5167-5174.

Higgins-OPitZ, S. B., DeTtMan, C. D., Dingle, C. E., ANDERSON, C. B. \& BECKER, P. J. (1990). Intestinal parasites of conventionally maintained $\mathrm{BALB} / \mathrm{c}$ mice and Mastomys coucha and the effects of a concomitant schistosome infection. Laboratory Animal Science 24, 246-252.

Hillgarth, N. \& WingField, J. C. (1995). Testosterone and immunosuppression in vertebrates: implications for parasite-mediated sexual selection. In Parasites and Pathogens. Effects on Host Hormones and Behavior (ed. Beckage, N. E.), pp. 143-155. New York: International Thomson Publishing.

HORNOK, S., HEIJMANS, J. F., BEKESI, L., PEEK, H. W., Dobos-Kovacs, M., DREN, C. N. \& VARGA, I. (1998). Interaction of chicken anaemia virus and Cryptosporidium baileyi in experimentally infected chickens. Veterinary Parasitology 31, 43-55.

Houba, v. (1988). Specific immunity: immunopathology and immunosuppression. In Malaria: Principles and Practice of Malariology (ed. Wernsdorfer, W. H. \& McGregor, I.), pp. 621-637. Edinburgh: Churchill Livingstone.

hovette, P., CAMARA, P., DOnZEL, C. \& RAPHenON, G. (1999). Paludisme et tuberculose pulmonaire: effet 'booster' du paludisme sur la tuberculose? Presse Médicale 28, 398-399.

HSU, D. Y. M. \& GEIMAN, Q. M. (1952). Synergistic effect of Haemobartonella muris on Plasmodium berghei in white rats. American Fournal of Tropical Medicine and Hygiene 1, 747-760.

HUDSON, K. M. \& TERRY, R. J. (1979). Immunodepression and the course of infection of a chronic Trypanosoma bruce $i$ infection in mice. Parasite Immunology $\mathbf{1}$, 317-326.

Hughes, F. W. \& TATuM, A. L. (1956). Effects of hypoxia and intercurrent infections on infections by Plasmodium berghei in rats. Fournal of Infectious Diseases 98, 38-43.

ISHAM, V. \& MEDLEy, G. (eds) (1996). Models for Infectious Human Diseases: Their Structure and Relation to Data. Cambridge: Cambridge University Press.

JAHIEL, R. I., NUSSENZWEIG, R. S., VANDERBERG, J. \& VILCEK, J. (1968 a). Antimalarial effect of interferon inducers at different stages of development of Plasmodium berghei in the mouse. Nature 220 , $710-711$

JAHIEL, R. I., VILCEK, J., NUSSENZWEIG, R. S. \& VANDERBERG, J. (1968 b). Interferon inducers protect mice against Plasmodium berghei malaria. Science 161, 802-804.
KAYE, P. (1999). Parasite derived immunoregulatory molecules. Parasite Immunology 21, 595-596.

KLEIN, J. \& HOŘEJŠí, v. (1997). Immunology, 2nd edn., pp. 291-326 Oxford: Blackwell Science.

Kloetzel, K., ChiefFi, P. P., FAleiros, J. J. \& Filho, T. J. (1977). Mortality and other parameters of concomitant infections in albino mice; the Schistosoma-Toxoplasma model. Tropical and Geographical Medicine 29, 407-410.

KLOETZEL, K., FAleiros, J. J. \& Mendes, S. R. (1971). Concurrent infection of white mice with T. cruzi and S. mansoni. Transactions of the Royal Society of Tropical Medicine and Hygiene 65, 530-531.

KRETTLi, A. U. (1977). Exacerbation of experimental Trypanosoma cruzi infection in mice by concomitant malaria. Fournal of Protozoology 24, 514-518.

LACROIX, C., BRUN-PASCAUd, M., MASLO, C., CHAU, F., ROMAND, S. \& DEROUIN, F. (1996). Co-infection of Toxoplasma gondii with other pathogens : pathogenicity and chemotherapy in animal models. In Toxoplasma gondii (ed. Gross, U. J.). Current Topics in Immunology and Microbiology, No. 219, pp. $223-233$

LIN, D. S. \& BOWMAN, D. D. (1992). Macrophage functions in cats experimentally infected with feline immunodeficiency virus and Toxoplasma gondii. Veterinary Immunology and Immunopathology 33, 69-78.

MA, X., ASTE-AMEZAGA, M., GRI, G., GEROSA, F. \& TRINCHIERI, G. (1997). Immunomodulatory functions and molecular regulation of IL-12. In $I L-12$. (ed. Aldorini, A), Chemical Immunology 68, 1-22. Basel: Karger.

MABEY, D. C. W., BROWN, A \& GREENWOOD, A. M. (1987). Plasmodium falciparum malaria and Salmonella infections in Gambian children. Fournal of Infectious Diseases 155, 1319-1321.

McGREGOR, I. A. \& BARR, M. (1962). Antibody response to tetanus toxoid inoculation in malarious and nonmalarious Gambian children. Transactions of the Royal Society of Tropical Medicine and Hygiene 56, 364-367.

MADWAR, M. A., EL TAHAWY, M. \& STRICKLAND, G. T. (1989). The relationship between uncomplicated schistosomiasis and hepatitis B infection. Transactions of the Royal Society of Tropical Medicine and Hygiene 83, 233-236.

MAitland, K., Williams, T. N. \& NEWBold, C. I. (1997). Plasmodium vivax and P. falciparum: biological interactions and the possibility of cross-species immunity. Parasitology Today 13, 227-231.

MALHOTRA, I., MUNGai, P., WAMACHi, A., KiOKO, J., OUMA, J. H., KAZURA, J. W. \& KING, C. L. (1999). Helminths and Bacillus-Calmette-Guerin-induced immunity in children sensitized in utero to filariasis and schistosomiasis. Fournal of Immunology 162, 6843-6848.

MANGOUD, A. M., RAMAdAN, M. E., MORSY, T. A., AMIN, A. M. \& MOstafa, S. M. (1998). The histopathological picture of the liver of hamsters experimentally infected with Leishmania d. infantum on top of Schistosoma mansoni infection. Journal of the Egyptian Society of Parasitology 28, 101-117.

MANSOUR, N. S., YOUSSEF, F. G., MIKHAIL, E. M. \& MOHAREB, E. W. (1997). Amebiasis in schistosomiasis 
endemic and non-endemic areas in Egypt. Fournal of the Egyptian Society of Parasitology 27, 617-628.

MARKELl, E. K., JOHN, D. T. \& KROTOSKI, W. A. (1999).

Markell and Voge's Medical Parasitology, 8th edn.

Philadelphia: W. B. Saunders.

MARSHALl, A. J., BRUNET, L. R., VAN GESSEL, Y., ALCARAZ, A., BLISS, S. K., PEARCE, E. J. \& DENKERS, E. Y. (1999).

Toxoplasma gondii and Schistosoma mansoni synergise to promote hepatocyte dysfunction association with high levels of plasma TNF- $\alpha$ and early death in C57BL/6 mice. Fournal of Immunology 163, 2089-2097.

MillotT, s. M. \& COX, F. E. G. (1985). Interactions between Trypanosoma brucei and Babesia spp. and Plasmodium spp. in mice. Parasitology 90, 241-254.

MING, M., EWEN, M. E. \& PEREIRA, M. E. (1995).

Trypanosome invasion of mammalian cells requires activation of the TGF beta signalling pathway. Cell 82, 287-296.

MODRIĆ, S. \& MAYBERRY, L. F. (1994). Effect of Plasmodium berghei (Apicomplexa) on Nippostrongylus brasiliensis (Nematoda) infection in the mouse Mus musculus. International Fournal for Parasitology 24, 389-395.

MORSY, T. A., MANGOUD, A. M., RAMADAN, M. E., MOSTAFA, S. M. \& EL-SHARKAWY, I. M. (1998). The histopathology of the intestine of hamsters infected with Leishmania d. infantum on top of pre-existing schistosomiasis mansoni. Fournal of the Egyptian Society of

Parasitology 28, 347-354.

mosmanN, T. R. \& COFFMAN, R. L. (1989). Heterogeneity of cytokine secretion patterns and functions of helper $\mathrm{T}$ cells. Advances in Immunology 46, 111-147.

OMER, F. M., KURTZhals, J. A. L. \& RILEy, E. M. (2000).

Maintaining the immunological balance in parasitic infections: a role for TGF- $\beta$. Parasitology Today 16, $18-23$.

ONAH, D. N. \& WAKELIN, D. (1999). Trypanosomeinduced suppression of responses to Trichinella spiralis in vaccinated mice. International Fournal for Parasitology 29, 1017-1026.

PETERS, W. (1965). Competitive relationship between Eperythrozoon coccoides and Plasmodium berghei in the mouse. Experimental Parasitology 16, 158-166.

PETNEY, T. N. \& ANDREws, R. H. (1998). Multiparasite communities. International Fournal for Parasitology 28, 377-393.

PHILliPS, R. S. \& WAKELIN, D. (1976). Trichuris muris: effect of concurrent infections with rodent piroplasma on immune expulsion from mice. Experimental Parasitology 39, 95-100.

POUlin, R. (1998). Evolutionary Ecology of Parasites. London, Chapman and Hall.

PRITCHARD, D. I., HEWITT, C. \& MOQBEL, R. (1997). The relationship between immunological responsiveness controlled by T-helper 2 lymphocytes and infections with parasitic helminths. Parasitology 115, S33-S44.

PURNOMO, SOLIHIN, A, GÓMEZ-SALADIN, E. \& BANGS, M. J. (1999). Rare quadruple malaria infection in Irian Jaya Indonesia. Fournal of Parasitology 85, 574-579.

RIFAAT, M. A., SALEM, S. A., AZAB, M. E., EL-RAZIK, I. A., SAFER, E. H., BESHIR, S. R. \& EL-SHENNAWY, S. F. (1984). Experimental concomitant toxoplasma and malaria infection in rats. Folia Parasitologica 31, 97-104.
ROBERTS-THOMSON, I. C., GROVE, D. I., STEVENS, D. P. \& WARREN, K. S. (1976). Suppression of giardiasis during the intestinal phase of trichinosis in the mouse. Gut 17, 953-958.

ROBERTSON, L. J., CROMPTON, D. W. T., SANJUR, D. \& NESHEIM, M. C. (1992). Haemoglobin concentrations and concomitant infections of hookworm and Trichuris trichiura in Panamanian primary schoolchildren. Transactions of the Royal Society of Tropical Medicine and Hygiene 86, 654-656.

RODRÍGUEZ, M., TERRAZAS, L. I., MÁRQUEZ, R. \& BOJALIL, R. (1999). Susceptibility to Trypanosoma cruzi is modified by a previous non-related infection. Parasite Immunology 21, 177-185.

romagnani, s. (1991). Human Th1 and Th2: doubt no more. Immunology Today 12, 256-257.

romagnani, s. (ed.) (1996). Th1 and Th2 Cells in Health and Disease. Chemical Immunology 63. Basel: Karger.

ROOTH, I. B. \& BJÖRKMAN, A. (1992). Suppression of Plasmodium falciparum infections during concomitant measles or influenza but not during pertussis. American Fournal of Tropical Medicine and Hygiene 47, 675-681.

Rose, M. E., WAKELIN, D. \& HESKETH, P. (1994). Interactions between infections with Eimeria spp. and Trichinella spiralis in inbred mice. Parasitology 108, $69-75$.

Rousseau, D., LE Fichoux, Y., STIEN, X, SUfFia, I., FERrua, B. \& KUBAR, J. (1997). Progression of visceral leishmaniasis due to Leishmania infantum in BALB/c mice is markedly showed by prior infection with Trichinella spiralis. Infection and Immunity $\mathbf{6 5}$, 4978-4983.

Salaman, M. H. (1969). Immunodepression by viruses. Antibiotics and Chemotherapy 15, 393-406.

SAlaman, M. H., WEDDERbURn, N. \& BRUCE-ChWATt, L. J. (1969). The immunodepressive effect of a murine plasmodium and its interaction with murine oncogenic viruses. Fournal of General Microbiology 59, 383-391.

SERGENT, E. (1937). La prémunition dans le paludisme. Rivista di Malariologia 14 (Suppl.), pp. 5-25.

SERGENT, E. \& PONCET, A. (1957). Étude expérimentale de l'association chez le rat blanc de la spirochétose hispano-nord-africaine et du paludisme des rongeurs a Plasmodium berghei. Annales de l'Institut Pasteur Algerie 35, 1-23.

SHEHU, K. \& NOWELl, F. (1998). Cross-reactions between Eimeria falciformis and Eimeria pragensis in mice induced by trickle infections. Parasitology 117, $457-465$.

SHMEUl, Z, GOLENSER, J. \& SPIRA D. T. (1975). Mutual influence of infection with Plasmodium berghei and Trypanosoma lewisi in rats. Fournal of Protozoology 22, Abstract 73a.

SILVA, J. S., BARRAL-NETTO, M. \& REED, S. G. (1993). Aggravation of both Trypenosoma cruzi and murine leukaemia virus by concomitant infections. American Fournal of Tropical Medicine and Hygiene 49, 589-597. SMALLEY, M. E. (1975). The nature of age immunity to Plasmodium berghei in the rat. Parasitology $\mathbf{7 1}$, 337-347.

SMith, T., FELGER, I., TANNER, M. \& BECK, H.-P. (1999). Premunition in Plasmodium falciparum infection: 
insights from the epidemiology of multiple infections. Transactions of the Royal Society of Tropical Medicine and Hygiene 93 (Suppl. 1), S59-S64.

SMithers, S. R., TERRY, R. J. \& HOCKLEY, D. J. (1969).

Host antigens in schistosomiasis. Proceedings of the Royal Society B 171, 483-494.

STEPHENSON, L. S. (1987). Impact of Helminth Infections of Human Nutrition. London: Taylor and Francis. STERNBERG J. M. (1998). Immunobiology of African trypanosomiasis. In Immunology of Intracellular Parasitism (ed. Liew, F. Y. \& Cox, F. E. G.), pp. 186-199. Chemical Immunology 70. Basel: Karger. STEWART, G. L., REDDINGTON, J. J. \& HAMILTON, A. M. (1980). Eimeria nieschulzi and Trichinella spiralis in the rat. Experimental Parasitology 50, 115-122.

STEWART, G. R., BOUSSINESQ, M., COULSON, T., ElSON, L., NUTMAN, T. \& BRADlEY, J. E. (1999). Onchocerciasis modulates the immune response to mycobacterial antigens. Clinical and Experimental Immunology 117, 517-523.

Strauss, E. \& LACET, C. M. C. (1986). Hepatite e esquistossomose mansönica. In Hepatites Agudas e Crônicas. São Paulo: Sarvier.

TANNER, M. \& BAKER, J. R. (eds) (1999). The Epidemiology of Multiple Plasmodium falciparum Infections.

Transactions of the Royal Society of Tropical Medicine and Hygiene 93 (Suppl. 1), S1-S68.

TAYLOR-ROBINSON, A. W. \& PHILlips, R. S. (1998). Infective dose moderates the balance between $\mathrm{Th}_{1}$ and $\mathrm{Th}_{2}$-regulated immune responses during bloodstage malaria. Scandinavian Fournal of Immunology 48, 527-544.

TOFT, C. A., Aeschlimann, A. \& Bolis, L. (eds) (1991). Parasite-Host Associations : Coexistence or Conflict? Oxford: Oxford University Press.

URQUHART, G. M., MURRAY, M., MURRAY, F. W., JENNINGS, F. W. \& BATE, E. (1973). Immunodepression in Trypanosoma brucei infections in rats and mice. Transactions of the Royal Society of Tropical Medicine and Hygiene 65, 528-535.

VERINAUd, L., DA CRUZ-HÖFling, M. A., SAKURADA, J. K., RANGel, H. A., VASSAllo, J., WAKelin, D., SEWEll, H. F. \& CAMARgO, I. J. (1998). Immunodepression induced by Trypanosoma cruzi and mouse hepatitis virus 3 is associated with thymus apoptosis. Clinical Diagnostic Laboratory Immunology 5, 186-191.

VIEIRA, L. Q., OlIVIERA, M. R., NEUMANN, E., NICOLL, J. R. \& VIEIRA, E. C. (1998). Parasitic infections in germfree mice. Brazilian Fournal of Medical and Biological Research 31, 105-110.

VINAYAK, v. K. \& CHOPRA, A. K. (1978). The interaction between Entamoeba histolytica and Syphacia obvelata infection in mice. Annals of Tropical Medicine and Parasitology 72, 549-551.

VOller, A., GARNhAM, P. C. C. \& TARGETT, G. A. T. (1966). Cross immunity in monkey malaria. Fournal of Tropical Medicine and Hygiene 69, 121-123.

WaKelin, D. (1996). Immunity to Parasites: How Parasitic Infections are Controlled. Cambridge: Cambridge University Press.

WAlsh, A. L., Phiri, A. J., GRAHAM, S. M., MOLYNEUX, E. M. \& MOLyneux, M. E. (2000). Bacteremia in febrile Malawian children: children and microbiologic features. Pediatric Infectious Disease Fournal 19, 312-318.

WEDDERBURN, N. (1970). Effect of concurrent malaria infection on development of virus-induced lymphoma in Balb/c mice. Lancet 2, 1114-1116.

WEDDERBURN, N. (1974). Immunodepression produced by malarial infection in mice. In Parasites in the Immunized Host. Mechanisms of Survival. Ciba Foundation Symposium No. 25 (new series), pp. 123-135. Amsterdam: Elsevier.

WhitTle, H. C., BRoWN, J., MARSh, K., GREENWOOD, B. M., SEIDELIN, P., TIGHE, H. \& WEDDERBURN, L. (1984). Tcell control of Epstein-Barr virus-infected B cells is lost during P. falciparum malaria. Nature 312, $449-450$.

WILLIAMSON, W. A. \& GREENWOOD, B. M. (1978). Impairment of the immune response to vaccination after severe malaria. Lancet 1, 1328-1329.

YOELI, M. (1956). Some aspects of concomitant infections of plasmodia and schistosomes. I. The effect of Schistosoma mansoni on the course of Plasmodium berghei in the field vole (Microtus guentheri). American Fournal of Tropical Medicine and Hygiene 5, 988-999.

YOELI, M., BECKER, Y. \& BERNKOPF, H. (1995). ['The effect of West Nile Virus on experimental malaria infection (Plasmodium berghei) in mice]. In Hebrew, Harefuah, Ferusalem 49, 116-119.

yoshida, A., Maruyama, H., YabU, Y., AMano, T., KOBAYAKAWA, т. \& OHTA, N. (1999). Immune responses against protozoal and nematodal infection in mice with underlying Schistosoma mansoni infection. Parasitology International 48, 73-79. 